\title{
Küreselleşme ve Kamu Harcamaları Bileşenleri Arasındaki İlişki: AB Ülkeleri Örneği
} (Araştırma Makalesi)

\author{
Nexus between Globalization and Public Expenditure Components: Case of \\ EU Countries
}

Doi: 10.29023/alanyaakademik.658540

Orhan CENGIZZ

Öğr. Gör. Dr., Çukurova Üniversitesi Pozantı MYO, Muhasebe ve Vergi Bölümü, ocengiz@cu.edu.tr

Orcid No: 0000-0002-1883-4754

Müge MANGA

Dr. Ögr. Üyesi, Erzincan Binali Yıldırım Üniversitesi, İ̈BF İktisat Bölümü, mangamuge@gmail.com

Orcid No: 0000-0003-2675-2182

Bu makaleye atıfta bulunmak için: Cengiz O., Manga M. (2020). "Küreselleşme ve Kamu Harcamaları Bileşenleri Arasındaki İlişki: AB Ülkeleri Örneği”, Alanya Akademik Bakış, 4(3), Sayfa No. 807-819.

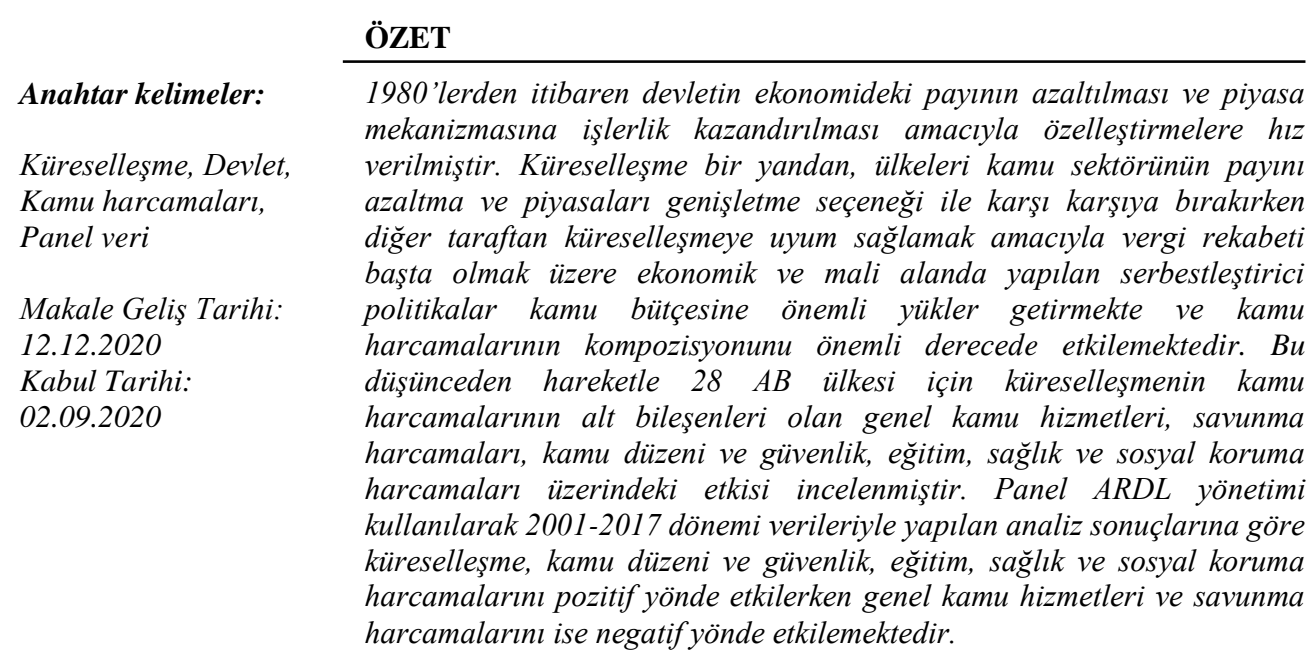

Keywords:

Globalization, State, Public expenditure, Panel data

\section{ABSTRACT}

Privatizations were accelerated to reduce share of state in economy and to activate market mechanism since 1980s. Thereby, globalization has exposed countries options that reducing public sector and expanding markets, on the other hand, liberalizing policies that are applied in the economic and financial fields, especially in tax competition to adapt 
globalization bring significant burdens on public budget and affect composition of public expenditures significantly. From this point of opinion, impact of globalization on general public services, defense expenditures, public order and safety, education, health and social protection expenditures which are sub-components of public expenditures is examined for 28 EU countries. Using by panel ARDL method over the years between 2001 and 2017, results show that while globalization positively affects public order and safety, education, health and social protection expenditures, negatively affects general public services and defense expenditures.

\section{GİRIŞ̧}

Küreselleşmenin kamu harcamaları üzerindeki etkisini inceleyen yaklaşımların ortaya koyduğu en önemli kavramsal çerçeve, küreselleşme ile birlikte ülkeler arasında yaşanan vergi rekabetinin refah devleti anlayışı kapsamında kamusal harcamalar üzerinde yarattığı etkiye yöneliktir.

Ekonomilerin dışa açıklığını ifade eden ekonomik küreselleşme ile kamu harcamaları arasındaki ilişkiye yönelik uzun süredir süregelen tartışmalar, genellikle "verimlilik (efficiency)" ve "kompansasyon (compensation)" hipotezleri kapsamında ele alınmaktadır. Uluslararası ekonomik entegrasyonun ulusal refah devleti politikaları ve kamu maliyesi üzerindeki etkisini inceleyen literatür giderek genişlemiştir (Busemeyer, 2009: 455). Garrett (2001)'e göre verimlilik hipotezi kapsamında devletin savunma, mülkiyet haklarını güvence altına alma ve diğer kamusal malların üretimi gibi piyasanın işleyişini kolaylaştıran politikaların ötesine geçen müdahaleleri, yurtiçindeki üreticilerin uluslararası mal ve hizmet piyasalarında rekabet güçlerini azaltmaktadır. Örneğin, gelir transferi ve sosyal hizmet programları işgücü piyasasını bozarak dönemler arası yatırım kararlarını manipüle etmektedir. Bunun yanında kamu harcamaları kısa vadede genellikle borçlanma yoluyla ve nihayetinde daha yüksek vergilerle finanse edilmek zorunda kalmaktadır. Gelir ve servet vergileri varlık sahiplerinin yatırım kararlarını aşındırmakta ve artan oranlı vergi sistemine yol açmaktadır. Borçlanma diğer yandan reel faiz oranlarını yükselterek yatırımları daha da baskılamaktadır. Dolayısıyla verimlilik hipotezine göre ticari açıklık ile kamu sektörü büyüklüğü arasındaki ilişkide sıfır toplamlı kalite söz konusudur (Garrett, 2001: 5-6). Üretimin ve yatırımın küreselleşmesi, devletlerin küresel ekonominin dominant gücü karşısında sosyal refah politikaları konusundaki özerkliğini yitirmesinden dolayı, refah devleti politikalarının yenilenmesini gerektirmektedir (Brady vd., 2005; Kim ve Zurlo, 2009: 131).

Verimlilik hipotezinde küreselleşmenin, devleti refah devleti programlarının azaltılmasına zorladığı argümanına karşılık, kompansasyon hipotezi, küreselleşme ile birlikte ortaya çıkan oynaklık ve ekonomik riskler sonucunda bireylerin zarar görmelerinden dolay1, devletin sosyal refah harcamalarının artacağını savunmaktadır (Cameron, 1978; Katzenstein, 1985; Quinn, 1997; Rodrik, 1996; Swank, 2002). Rodrik (1996)'e göre ülkeler, uluslararas1 piyasalara entegre oldukça bireyler karşılaşabilecekleri risklerin ve güvensizliklerin karşılığını devletten talep ederler. Hükümetler de bu talebe sosyal programlar ve kamu istidamı yoluyla karşı1ık verirler (Rodrik, 1996: 26; Rodrik, 2011: 16). 
Devletin müdahale etmemesi durumunda piyasanın mevcut kaynakların alternatif kullanım alanları arasında en verimli sonuçları yaratacağını belirten neo-klasik görüş, devletlerin kapsamlı sosyal koruma sağlama yeteneklerini sınırlamaktadır. Ulusal piyasalar dünya piyasalarına daha fazla entegre oldukça, gelişmiş ülke üreticilerinin az gelişmiş ülkelerdeki üreticilerle rekabet etmeleri gerekmektedir. Yatırımcıların ve üreticilerin geniş harcama programlarına dayanan refah rejimleri kapsamında faaliyet göstermeleri durumunda, yüksek sosyal refah ile ilişkilendirilen vergi yükleri, düzenleyici engellerin fazlalığı, işgücü piyasası ve emek mobilitesinin katılığı nedeniyle etkin biçimde rekabet edemezler. Dış ticarete açıklık, rekabete maruz kalan sektörler üzerinde baskıyı arttırdığı için devlet, yatırımcıların ve üreticilerin ticaret sektöründeki rekabetini güçlendirecek taleplerle karşı karşıya kalmaktadır. $\mathrm{Bu}$ nedenle açık ekonomilerde politika yapıcılar, ihracatta fiyat rekabetini güçlendirmek ve işgücü maliyetlerini azaltmak amacıyla yerli üreticiler üzerindeki sosyal güvenlik vergi yüklerini azaltma baskısıyla karşılaşmaktadır (Ha, 2008: 786).

Neo-liberal ekonomik argümana karşı çıkan yaklaşımlar ise, küreselleşmenin refah harcamalarını arttırdığını savunmaktadır. Bu yaklaşımlara göre her ne kadar ticaret ve yatırımlardaki serbestleşme ekonomik açıdan faydalar sağlasa da bu faktörler, firmalar ve sektörler arasında gelirlerin dengesiz dağılımına yol açarak sosyal düzensizliği ve ekonomik güvensizliği arttırmaktadır. Tüm bu yükler, devleti işgücünü ve firmaları dışa açıklığın risklerinden doğrudan ve dolaylı koruma önlemleri almaya zorlamaktadır (Ha, 2008: 786).

Ekonomik entegrasyon sonucu, ulusal ekonomilerin dünya ekonomisindeki dalgalanmalara maruz kalmaları yurtiçinde güvensizliğin ortadan kaldırılması için devletin daha fazla sosyal koruma sağlamasını zorunlu kılmaktadır. Diğer ifadeyle, ekonomik küreselleşme sonucu dışa açıklığın artması, ekonomik ve sosyal olumsuzlukları azaltan telafi edici kamu harcamalarına yönelik talebi arttırmaktadır (Kim, 2007: 182).

Dreher vd. (2008), gerek verimlilik gerekse de kompansasyon hipotezinde, odaklanılan sosyal devlet harcamaları yanında diğer kamu harcamaları kategorilerinin de bütçe politikası üzerinde etkili olduğunu, dolayısıyla küreselleşmenin belirli harcamalar üzerindeki etkisini ölçebilmek için diğer harcamaların da dikkate alınması gerektiğini ileri sürmüştür. Çünkü kompansasyon hipotezine göre, genel kamu harcamalarının seviyesi değişmeden kalsa bile kamu harcamalarının bazı bileşenleri daha önemli olabilmektedir (Dreher vd., 2008: 265). Buradan hareketle çalışmada AB-28 için küreselleşmenin sadece sosyal refah harcamaları üzerindeki etkisi değil, genel kamu hizmetleri, savunma, kamu düzeni ve güvenlik gibi diğer unsurlar üzerindeki etkisi de test edilmiştir.

Tablo 1. AB-28 Seçilmiş Kamu Harcamaları ve Bileşenlerinin GSYH İçerisindeki Payı (\%)

\begin{tabular}{|l|c|c|c|c|c|c|c|}
\hline & $\begin{array}{c}\text { Genel Kamu } \\
\text { Harcamaları }\end{array}$ & $\begin{array}{c}\text { Genel Kamu } \\
\text { Hizmetleri }\end{array}$ & Savunma & $\begin{array}{c}\text { Kamu Düzeni ve } \\
\text { Güvenlik }\end{array}$ & Sağlık & Ĕgitim & Sosyal Koruma \\
\hline $\mathbf{2 0 0 1}$ & 45.1 & 7.0 & 1.5 & 1.7 & 6.0 & 4.9 & 17.3 \\
\hline $\mathbf{2 0 0 2}$ & 45.5 & 6.8 & 1.5 & 1.8 & 6.2 & 5.0 & 17.5 \\
\hline $\mathbf{2 0 0 3}$ & 46.2 & 6.6 & 1.5 & 1.8 & 6.4 & 5.1 & 17.9 \\
\hline $\mathbf{2 0 0 4}$ & 45.8 & 6.5 & 1.5 & 1.8 & 6.4 & 5.0 & 17.7 \\
\hline $\mathbf{2 0 0 5}$ & 45.8 & 6.5 & 1.5 & 1.8 & 6.5 & 5.0 & 17.6 \\
\hline $\mathbf{2 0 0 6}$ & 45.2 & 6.3 & 1.5 & 1.8 & 6.6 & 4.9 & 17.3 \\
\hline
\end{tabular}


CENGIZ \& MANGA

\begin{tabular}{|l|l|l|l|l|l|l|l|}
$\mathbf{2 0 0 7}$ & 44.6 & 6.3 & 1.4 & 1.7 & 6.5 & 4.9 & 17.0 \\
\hline $\mathbf{2 0 0 8}$ & 46.2 & 6.5 & 1.5 & 1.8 & 6.7 & 4.9 & 17.4 \\
\hline $\mathbf{2 0 0 9}$ & 50.0 & 6.7 & 1.5 & 1.9 & 7.3 & 5.2 & 19.4 \\
\hline $\mathbf{2 0 1 0}$ & 49.9 & 6.7 & 1.5 & 1.9 & 7.3 & 5.2 & 19.3 \\
\hline $\mathbf{2 0 1 1}$ & 48.5 & 6.9 & 1.5 & 1.8 & 7.1 & 5.1 & 19.0 \\
\hline $\mathbf{2 0 1 2}$ & 48.9 & 6.9 & 1.4 & 1.8 & 7.1 & 5.0 & 19.3 \\
\hline $\mathbf{2 0 1 3}$ & 48.6 & 6.9 & 1.4 & 1.8 & 7.2 & 4.9 & 19.5 \\
\hline $\mathbf{2 0 1 4}$ & 47.9 & 6.6 & 1.3 & 1.7 & 7.2 & 4.9 & 19.3 \\
\hline $\mathbf{2 0 1 5}$ & 46.9 & 6.2 & 1.3 & 1.7 & 7.1 & 4.8 & 19.1 \\
\hline $\mathbf{2 0 1 6}$ & 46.2 & 6.0 & 1.3 & 1.7 & 7.1 & 4.7 & 19.0 \\
\hline $\mathbf{2 0 1 7}$ & 45.8 & 5.8 & 1.3 & 1.7 & 7.0 & 4.6 & 18.8 \\
\hline
\end{tabular}

Kaynak: Eurostat verilerinden yararlanılarak yazarlar tarafindan oluşturulmuştur.

Tablo 1'de AB-28 için seçilmiş kamu harcamalarının bileşenleri gösterilmektedir. Genel kamu harcamalarının GSYH içerisindeki payı dikkate alındığında söz konusu dönem içerisinde oldukça istikrarlı bir seyir izlediği görülmektedir. Kamu harcamalarının bileşenleri içerisindeki en büyük pay, sosyal koruma harcamalarına aittir. Genel kamu hizmetleri, sağlık ve eğitim harcamalarının GSYH'deki payı birbirine oldukça yakın olmasına rağmen, kamu düzeni \& güvenlik ve savunma harcamalarının payının oldukça düşük olduğu görülmektedir. Sosyal koruma harcamalarının payının yüksek olmasında etkili olan unsurların başında, AB ülkelerinde yaşlı bağımlılık oranının ${ }^{1}$ yüksek olması gelmektedir. UNCTAD (2019) verilerine göre, 2019 yılı itibariyle yaşlı bağımlılık oranının dünya ortalaması \% 14 iken, AB ülkelerinde \% 31,4'tür. 2050 yılında ise bu oranın sırasıyla dünya ortalaması için \% 25,3 olması beklenirken, $\mathrm{AB}$ için dünya ortalamasının iki katından daha fazla yükselerek \% 53,3 olacağı tahmin edilmektedir.

\section{LITERATÜR İNCELEMESI}

Küreselleşmenin kamu sektörü büyüklüğü üzerindeki etkisi genel itibariyle iki çerçevede ilerlemiştir. Bunlardan ilki verimlilik hipotezi diğeri ise kompansasyon hipotezidir. İlgili literatür incelendiğinde küreselleşme-kamu harcamaları ilişkisi daha çok gelişmiş ülkeler nezdinde ele alınmıştır. Çünkü ticari ve finansal açıklık gelişmiş ülkelerde daha olgun bir seviyede olduğu için küreselleşmenin kamu politikalarına etkisini ölçmek daha sağlıklı sonuçlar vermektedir. Bu kapsamda incelenen bazı çalışmaların ulaştığı sonuçlar aşağıda özetlenmiştir.

Küreselleşmenin kamu harcamalarının bileşenleri üzerindeki etkisini inceleyen çalışmaların en önemlilerinden birisi Dani Rodrik (1996)'e aittir. Yazar, Cameron (1978)'ın 18 OECD ülkesi için uluslararası ticareti gelişmiş ülkelerde kamu sektörünün neden büyüdüğü sorusunu araştırdığı çalışmasını genişleterek, 100'den fazla ülke için uluslararası ticari açıklık ile kamu harcamalarının kompozisyonu arasındaki ilişkiyi incelemiştir. Elde edilen sonuçlara göre,

\footnotetext{
${ }^{1}$ Yaşlı bağımlılık oranı, 15-64 yaş aralığında yer alan çalışma çağındaki nüfustaki her 100 kişiye düşen 65 yaş ve üzeri yaşlı kişi sayısını ifade etmektedir (World Bank, 2020).

810
} 
dışa açıklık genel kamu hizmetleri, eğitim, sağlık, konut ve toplum tesisleri, ekonomik ilişkiler ve hizmetleri kapsayan kamu harcamaları üzerinde pozitif etkiye sahiptir. Rodrik (1996), bu sonucu uluslararası ticaretle birlikte meydana gelen dışsal şoklar sonucu yurtiçinde oluşan riskin hafifletilmesi amacıyla kamu harcamalarının stabilize edici rolüne yönelik talep artışıyla ilişkilendirmektedir.

Garrett ve Mitchell (2001), 18 OECD ülkesi için 1961-1993 dönemi verileriyle geniş kapsamlı küreselleşme göstergelerinin refah devleti politikaları üzerindeki etkisini ölçmüştür. Küreselleşme göstergeleri olarak toplam ticaret, düşük ücretli ülkelerden yapılan ithalat, doğrudan yabancı yatırım ve finansal entegrasyon kullanılmıştır. Refah politikaları, sosyal hizmetler ve gelir transferini kapsayan kamu harcamaları ile efektif sermaye vergilendirme oranı ile sermaye vergisinin emek ve tüketim vergisine oranını içeren vergilendirme kapsamında iki ayrı kategori olarak ifade edilmiştir. Ulaşılan sonuçlar, toplam ticaret ve finansal entegrasyonun kamu harcamalarını azalttı̆̆ını göstermektedir. Buna karşılık küresel piyasalara entegrasyonun (düşük ücretli ülkelerden yapılan ithalat, doğrudan yabancı yatırım ve finansal entegrasyon) sermaye vergisi oranlarındaki düşüş ve vergilendirme yükünün sermayeden tüketime ve emek gelirine kaymasıyla ilgili herhangi bir ilişkisi söz konusu değildir. Son olarak ülkeler, doğrudan yabancı yatırım akımlarının artması karşısında sermayeye daha fazla vergi uygulama eğilimindedir.

Bretschger ve Hettich (2002), 1967-1996 periyoduna ait verileri kullanarak 14 OECD ülkesi için küreselleşme, vergilendirme ve sosyal harcamalar arasındaki ilişkiyi araştırmıştır. Elde edilen sonuçlara göre küreselleşme kurumlar vergisi üzerinde negatif etkiye sahipken emek geliri üzerinden alınan vergi ve sosyal harcamalar üzerinde pozitif etkiye sahiptir. Sonuçlar birlikte değerlendirildiğinde küreselleşmenin kurumlar vergisini negatif etkilemesi; verimlilik hipotezini desteklerken, emek geliri üzerinden alınan vergiyi ve sosyal harcamaları pozitif etkilemesi ise kompansasyon hipotezini doğrulamaktadır.

Sanz ve Velázquez (2003), 1970-1997 dönemi verileriyle 26 OECD ülkesi için dışa açıklığın kamu harcamalarının bileşimi üzerindeki etkisini incelemiştir. Dışa açıklığı temsilen modele dâhil edilen doğrudan yabancı yatırım (DYY) stokunun kamu harcamalarının bileşimi üzerindeki etkisi değişkenlik göstermektedir. Buna göre dışa açıklık; sosyal güvenlik, sağlık ve kamu hizmetleri gibi sosyal harcamaların payını arttırırken, savunma, eğitim, konut, ekonomik hizmetler, ulaşım ve haberleşme harcamalarının payını ise azaltmaktadır. Dışa açıklığın sosyal harcamaları artırması, Rodrik (1996)'in dışa açıklığın bireyler üzerinde riskler yaratmasından dolayı özellikle sosyal refah harcamalarının artacağını öngören yaklaşımıyla paralellik arz etmektedir.

Brady vd. (2005), küreselleşmenin refah devleti üzerindeki etkisini 1975-2001 dönemi verileriyle 17 gelişmiş ülke için test etmiştir. Çok geniş sonuçların ortaya konulduğu araştırmada ekonomik küreselleşme göstergelerinin çoğunun refah harcamaları üzerinde çok önemli etkiye sahip olmadığını; fakat bazılarının refah devleti anlayışını az da olsa etkilediğini göstermektedir. Diğer yandan küreselleşmenin etkileri, Avrupa ile Avrupa dışındaki ülkeler arasında veya liberal ve liberal olmayan refah rejimleri arasında sistematik olarak farklı değildir. Küreselleşmenin artmasıyla refah devletinin genişlediği, krize girdiği veya küçüldüğü ile ilgili net bir sonuç söz konusu değildir. Dolayisıyla yazarlar, küreselleşmenin refah devleti üzerindeki etkisine şüphe ile yaklaşmaktadır. 
Dreher (2006), 1970-2000 döneminde 30 OECD ülkesi için yaptığı analizde küreselleşmenin kamu harcamaları, emek geliri üzerinden alınan vergi ve tüketim vergisi üzerinde anlamlı bir etkiye sahip olmadığı, sermaye vergisi üzerinde ise pozitif etkiye sahip olduğu bulgusunu elde etmiştir.

Carmignani vd. (2007)'nin 1970-2000 dönemi için 79 ülkede kamu harcamalarının büyüme oynaklığına etkisini küreselleşme ve kurumsal faktörlerin rolünü dâhil ederek incelediği çalışmasında, kamu harcamalarının büyüme oynaklığı üzerinde istikrarsızlaştırıcı etkilere yol açtığı bulgusuna ulaşmıştır. Buna ilave olarak küreselleşmeyi temsil eden finansal ve ticari açıklık, oynaklık üzerinde doğrudan ve dolayı etkilere sahiptir. Finansal açıklık doğrudan oynaklığı artırmakta; fakat aynı zamanda kamu harcamalarını ve dolaylı olarak oynaklığı azaltmaktadır. Ticari açıklık ise sadece risklere yol açmamakta bunun yanında yeniden dağıtım politikalarını da baskılamaktadır.

Liberati (2007), ABD, Kanada, Avustralya, Yeni Zelanda ve Japonya ile birlikte Avrupa ülkelerini de kapsayan toplam 20 ülkede ticari ve sermaye açıklığının kamu harcamalarını azalttığı sonucuna ulaşmıştır. Bu bulgular, dışa açıklığın kamu harcamalarını arttıracağını öngören kompansasyon hipotezine karşılık verimlilik hipotezini desteklemektedir.

Dreher vd. (2008), küreselleşmenin kamu harcamalarının bileşenleri üzerindeki etkisini farklı veri seti ve çeşitli küreselleşme göstergeleri kullanarak incelemiştir. İlk örneklem, 60 ülke için 1970-2001 dönemi verileriyle sermaye, mal \& hizmet, faiz ödemeleri \& sübvansiyonlar ve diğer cari harcamalardan oluşan dört geniş harcama kategorisini kapsarken, ikinci örneklem grubu 1990 sonrası periyoduna ilişkin 15 OECD ülkesi için çok daha ayrıntılı bir sınıflandırmayı içeren kamu hizmetleri, savunma, kamu düzeni \& güvenliği, ekonomik ilişkiler, çevre koruma; konut ve toplum tesisleri, sağlık, rekreasyon, kültür \& din, eğitim ve sosyal harcamalardan oluşmaktadır. Elde edilen sonuçlar, teorik olarak ileri sürülen küreselleşmenin güçlü etkilerini desteklememektedir. Dolayısıyla küreselleşmenin kamu harcamalarının kompozisyonunun etkilemediği sonucuna ulaşmışlardır.

Ha (2008), 18 gelişmiş sanayi ülkesi için 1960-2000 dönemi verileriyle küreselleşmenin ve yerel siyasi kurumlarla (veto oyuncuları) etkileşiminin refah devletini şekillendirmedeki rolünü araştırdığı analizinde, küreselleşmenin refah harcamalarını arttırdığını, bununla birlikte veto oyuncuları arasındaki ideolojik uzaklık arttıkça küreselleşmenin refah harcamaları üzerindeki baskısının azaldığı sonucuna ulaşmıştır. Ayrıca küreselleşme, devletlere refah harcamalarını genişletme yönünde baskı yapmasına rağmen, devletlerin bu duruma karşılık verme seçenekleri refah devleti politikasını değiştirmek için anlaşmaları gereken veto oyuncuları arasındaki ideolojik uzaklığa ve sayıya bağlı olmaktadır.

Kim ve Zurlo (2009), 1980-2001 periyoduna ait verilerle 18 gelişmiş ülkede küreselleşme ile sosyal refah harcamaları arasındaki ilişkiyi liberal, muhafazakâr ve sosyal demokrat rejimler özelinde ele almıştır. Elde edilen bulgular, küreselleşmenin sosyal refah harcamalarına olan etkisinin rejim türlerine göre değiştiğini ortaya koymaktadır. Buna göre küreselleşme tüm rejimlerde sosyal refah harcamalarını azaltırken; sosyal demokrat rejimlerdeki azalış liberal ve muhafazakâr rejimlerden üç kattan daha fazladır.

Shahbaz vd. (2010), Pakistan ekonomisi için ticari ve finansal açıklığın kamu sektörü büyüklüğü üzerindeki etkisini ölçtükleri çalışmada, ticari açıklığın kamu sektörünü pozitif yönde etkilediği dolayısıyla ticari açıklık arttıkça kamu harcamalarının da arttığı ortaya konulmuştur. Bu sonuçlar daha önce bahsedilen Cameron (1978) ve Rodrik (1996) tarafindan 812 
ortaya atılan tezleri desteklemektedir. Finansal açıklık ile kamu harcamaları arasında ise, zıt yönlü anlamsız bir ilişki bulunmuştur.

Bergh ve Karlsson (2010), 29 OECD ülkesinde 1970-1995 ve 1970-2005 şeklinde iki farklı zaman periyodunu dikkate alarak kamu sektörü büyüklüğü ve ekonomik büyüme ilişkisini ekonomik özgürlük ve küreselleşme göstergelerinin etkisini dikkate alarak incelemiştir. Elde edilen bulgulara göre, kamu sektörü büyüklüğü belirgin bir biçimde ekonomik büyümeyle negatif korelasyona sahiptir. Ayrıca, kamu sektörü büyük olan ülkeler bu durumun yarattığı negatif etkileri azaltabilmek için dişa açık ekonomi politikaları uygulamaktadır.

Wu vd. (2016), küreselleşme ile savunma harcamaları arasındaki nedensellik ilişkisini 19882011 dönemine ait verilerle G-7 ülkeleri için ele almışlardır. Tek yönlü Granger nedensellik sonuçlarına göre, küreselleşme Almanya ve Japonya'da savunma harcamalarını azaltırken, sadece İtalya'da küreselleşme ile savunma harcamaları arasında iki yönlü bulgu elde edilmiştir. Bir bütün olarak ele alındığında ise küreselleşmenin savunma harcamalarını negatif etkilediği ortaya konulmuştur.

Ampirik çalışmaların genelinde küreselleşmenin genel itibariyle kamu harcamaları ve vergilendirme kanalıyla kamu sektörü politikasını nasıl etkilediği dikkate alınmaktadır. Esasen dışa açıklık (ticari ve finansal) kavramıyla özdeş olarak kullanılan küreselleşmenin kamu harcamalarının bileşenleri üzerindeki etkisinin ayrı ayrı incelenmesi spesifik bulguların elde edilmesi ve daha kapsamlı politika önerilerinin sunulması açısından oldukça önemlidir. Dolayısıyla çalışmada AB ülkeleri için küreselleşmenin kamu harcamalarının alt bileşenlerine olan etkisi ayrı ayrı incelenerek ilgili literatüre katkı sunulması amaçlanmaktadır.

\section{VERI, YÖNTEM, MODEL VE BULGULAR}

Bu çalışmada, 2001-2017 dönemine ait verilerle 28 Avrupa Birliği ülkesi için (Avusturya, Belçika, Bulgaristan, Güney Kıbrıs Cumhuriyeti, Çek Cumhuriyeti, Danimarka, Estonya, Finlandiya, Fransa, Almanya, Yunanistan, Macaristan, İrlanda, İtalya, Letonya, Litvanya, Lüksemburg, Malta, Hollanda, Polonya, Portekiz, Romanya, Slovakya, Slovenya, İspanya, İsveç, Birleşik Krallık ve Hırvatistan) küreselleşme ile kamu harcamalarının alt bileşenleri arasındaki ilişski test edilmektedir. Yapılan çalışmada ampirik modelin oluşması aşamasında Dreher vd. (2008)'nin çalışması esas alınmıştır. Bu çerçevede oluşturulan model,

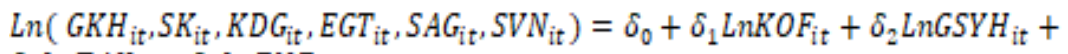

$\delta_{2} \operatorname{LnTAX_{it}}+\delta_{4} \operatorname{LnENF_{it}}+\varepsilon_{\text {it }}$

şeklinde belirlenmiştir.

Model de yer alan değişkenlerden, GKH, genel kamu hizmetleri, SK, sosyal koruma, KDG, kamu düzeni ve güvenlik, EGT, eğitim, SAG, sağlık ve SVN, savunma harcamalarının GSYH içerisindeki payını ifade etmektedir. KOF küreselleşme endeksini, GSYH, Gayri Safi Yurtiçi Hasılayı (2010 yılı sabit fiyatlarıyla), TAX, vergi gelirlerini, ENF ise GSYH deflatörüne göre sürekli fiyat artışlarındaki değişimi ifade etmektedir. Kamu harcamalarına ilişkin veri setleri Eurostat veritabanından, KOF endeksi, Gygli vd. (2019)'den GSYH, TAX ve ENF verileri ise Dünya Bankasından elde edilmiştir.

Burada kamu harcamalarının bileşenlerini oluşturan unsurların neyi ifade ettiği Tablo 2'de sunulmuştur. 
Tablo 2. Kamu Harcamalarının Bileşenleri ve Kapsamı

\begin{tabular}{|c|c|}
\hline Harcama Türü & Kapsamı \\
\hline Genel Kamu Hizmetleri & $\begin{array}{l}\text { Yürütme ve yasama organları, finansal ve mali işler, dış } \\
\text { ilişkiler; dış ekonomik yardım; genel hizmetler; temel } \\
\text { araştırma; genel kamu hizmetleri ile ilgili Ar-Ge; başka } \\
\text { yerde sınıflandırılmamış genel kamu hizmetleri unsurları; } \\
\text { kamu borç işlemleri, farklı kamu düzeyleri arasında genel } \\
\text { nitelikteki transferler }\end{array}$ \\
\hline Savunma & $\begin{array}{l}\text { Askeri savunma; sivil savunma; dış askeri yardım, savunma } \\
\text { ile ilgili Ar-Ge; başka yerde sınıflandırılmamış savunma } \\
\text { unsurları }\end{array}$ \\
\hline Kamu Düzeni ve Güvenlik & $\begin{array}{l}\text { Polis hizmetleri; yangından korunma hizmetleri; } \\
\text { mahkemeler; hapishaneler; kamu düzeni ve güvenliği ile } \\
\text { ilgili Ar-Ge; başka yerde sınıflandırılmamış kamu düzeni ve } \\
\text { güvenliği unsurları }\end{array}$ \\
\hline Sağlık & $\begin{array}{l}\text { Tibbi ürünler, cihazlar ve ekipmanlar; ayakta tedavi } \\
\text { hizmetleri; hastane hizmetleri; halk sağlığı hizmetleri; } \\
\text { sağlıkla ilgili Ar-Ge; başka yerde sınıflandırılmamış sağlık } \\
\text { unsurları }\end{array}$ \\
\hline Ĕ̆itim & $\begin{array}{l}\text { Okul öncesi, ilköğretim, ortaöğretim ve yükseköğretim, lise } \\
\text { sonrası yüksekögretim seviyesinde olmayan eğitim, } \\
\text { kategorisi tanımlanamayan eğitim, eğitime yardımc1 } \\
\text { hizmetler, eğitim ile ilgili AR-GE }\end{array}$ \\
\hline Sosyal Koruma & $\begin{array}{l}\text { Hastalık ve sakatlık; yaşlılık; sağ kalanlar; aile ve çocuklar; } \\
\text { işsizlik; konut; Ar-Ge; sosyal koruma ve sosyal dışlanma, } \\
\text { başka yerde sınıflandırılmamış sosyal koruma unsurları }\end{array}$ \\
\hline
\end{tabular}

Kaynak: Eurostat veritabanından elde edilmiştir.

Yapılan analizin ilk aşamasında mevcut seriler için birim kök sınaması yapılmıştır. Bu çerçevede ilk olarak yatay kesit bağımlılığını dikkate almayan birim kök testlerinden Im, Pesaran ve Shin (2003)-IPS ve yatay kesit bağımlılığını dikkate alan ve Pesaran (2007) tarafından ortaya atılan Yatay kesit Genişletilmiş Im, Pesaran ve Shin (Cross-Sectionally Augmented IPS-CIPS) testinden faydalanılmıştır. Yapılan birim kök testleri üzerine elde edilen bulgular Tablo 3 'te yer almaktadır.

Tablo 3. Birim Kök Testi Sonuçları

\begin{tabular}{|l|c|c|c|}
\hline Düzey Seviyede & \multicolumn{2}{|c|}{ LLC } & CIPS \\
\hline Değişkenler & (a) & (b) & (a) \\
\hline GKH & 0.523 & 0.902 & -1.866 \\
\hline SK & $-3.390^{* *}$ & $-1.432^{* *}$ & -1.519 \\
\hline KDG & $-1.766^{* *}$ & $-1.600^{* *}$ & -2.008 \\
\hline EGT & $-2.106^{* *}$ & $-2.728^{* *}$ & -1.717 \\
\hline SAG & $-3.333^{* *}$ & $-2.500^{* *}$ & -1.804 \\
\hline SVN & $-3.845^{* * *}$ & $-4.556^{* * *}$ & $-2.170^{*}$ \\
\hline KOF & $-10.139^{* * *}$ & $-6.373^{* * *}$ & -1.962 \\
\hline
\end{tabular}


ALANYA AKADEMİK BAKIŞ DERGİSİ 4/3 (2020)

\begin{tabular}{|c|c|c|c|}
\hline GSYH & -0.198 & $-3.014 * *$ & -1.365 \\
\hline TAX & -1.216 & -1.320 & -1.947 \\
\hline ENF & $-2.371 * *$ & $-1.430 * *$ & $-3.436 * * *$ \\
\hline 1.Farkında & \multicolumn{2}{|c|}{ LLC } & CIPS \\
\hline & (a) & (b) & (a) \\
\hline GKH & $-6.519 * * *$ & $-6.385 * * *$ & $-3.953 * * *$ \\
\hline SK & $-9.873 * * *$ & $-9.663 * * *$ & $-2.759 * * *$ \\
\hline KDG & $-7.235 * * *$ & $-5.608 * * *$ & $-4.093 * * *$ \\
\hline EGT & $-12.471 * * *$ & $-10.758 * * *$ & $-4.228 * * *$ \\
\hline SAG & $-10.101 * * *$ & $-9.909 * * *$ & $-3.543 * * *$ \\
\hline SVN & $-9.731 * * *$ & $-8.446 * * *$ & $-3.881 * * *$ \\
\hline KOF & $-8.585 * * *$ & $-10.333 * * *$ & $-3.918 * * *$ \\
\hline GSYH & $-7.724 * * *$ & $-6.470 * * *$ & $-2.385 * *$ \\
\hline TAX & $-6.248 * * *$ & $-4.484 * * *$ & $4.402 * * *$ \\
\hline ENF & $-2.753 * *$ & -0.449 & $-4.954 * * *$ \\
\hline
\end{tabular}

Not: (a) ve (b) sütunları sırasıyla, sabit, sabit+trend koşullarını göstermektedir. *,**,***, \%10, \%5 ve $\% 1$ düzeyinde anlamlılı̆̆ ifade etmektedir.

LLC birim kök testi sonuçlarına göre, GKH ve TAX değişkenleri birinci düzeyde I(1), modelde yer alan diğer değişkenler ise düzeyde $\mathrm{I}(0)$ durağanlık göstermektedir. Yatay kesit bağımlılığını dikkate alan CIPS birim kök testi sonuçlarına göre ise, SVN ve ENF değişkenleri düzeyde, diğer değişkenler ise birinci farkında durağanlık göstermektedir. Farklı düzeyde durağanlık gösteren seriler arasındaki uzun ve kısa dönemli ilişkinin tespit edilmesinde Panel ARDL modelinden faydalanılmıştır. Panel ARDL modeli uygulamalarından PMG ve MG arasındaki seçim için Hausman Testi Yapılmıştır. (1) nolu denklemde yer alan model için Panel ARDL denklemi;

$\operatorname{Ln}\left(G K H_{x} S K_{s} K D G_{s} E G T_{v} S A G_{s} S V N\right)_{\text {it }}=$

$\alpha_{i}+\sum_{j=1}^{p} \beta_{i j} \operatorname{Ln}\left(G K H_{s} S K_{v} K D G_{v} E G T_{v} S A G_{v} S V N\right)_{i t-j}+\sum_{j=0}^{q} \delta_{i j} L n K O F_{i t-j}+$

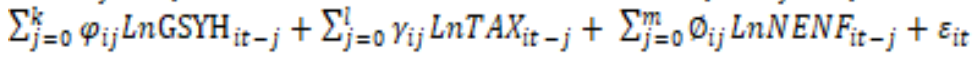

Şeklinde yazılmaktadır. Burada yer alan $\mathrm{i}=1,2,3, \ldots \mathrm{N} \rightarrow$ yatay kesit sayısını, $\mathrm{t}=1,2,3, \ldots \mathrm{T}$ ise zaman boyutunu ifade etmektedir.

Ayrıca, Panel ARDL modelinin hata düzeltme formaları ise,

$\Delta\left(G K H_{x} S K_{x} K D G_{x} E G T_{x} S A G_{x} S V N\right)_{\text {it }}=$

$\alpha_{i}+\beta_{i}^{v} \operatorname{Ln}\left(G K H_{x} S K_{x} K D G_{x} E G T_{s} S A G_{x} S V N_{i t-1}\right)+\delta_{i}^{t} L n K O F_{i t}+\varphi_{i}^{v} \operatorname{LnGSYH_{it}}+$

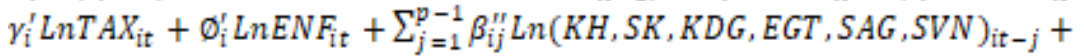

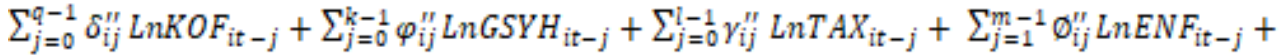
$\varepsilon_{\text {it }}$

şeklinde ifade edilebilir.

Denklemlerde yer alan $\beta_{i}^{x}$, hata düzeltme katsayısını, değişkenlerin düzeyleri üzerine konulan parametreler uzun dönem, birinci farkları üzerine konulan parametreler ise kısa dönem 
katsayıları göstermektedir (Nazlığlu, 2011: 74). Elde edilen uzun ve kısa dönemli tahmin katsayıları Tablo 4'te yer almaktadır.

Tablo 4. Panel ARDL/PMG Sonuçları

\begin{tabular}{|c|c|c|c|c|c|c|}
\hline & $\begin{array}{c}\text { Genel } \\
\text { Kamu } \\
\text { Hizmetleri } \\
(\text { GKH })\end{array}$ & $\begin{array}{c}\text { Sosyal } \\
\text { Koruma } \\
\text { (SK) }\end{array}$ & $\begin{array}{c}\text { Kamu } \\
\text { Düzeni ve } \\
\text { Güvenlik } \\
\text { (KDG) }\end{array}$ & $\begin{array}{l}\text { Ĕ̆itim } \\
\text { (EGT) }\end{array}$ & $\begin{array}{l}\text { Sağlık } \\
\text { (SAG) }\end{array}$ & $\begin{array}{c}\text { Savunma } \\
\text { (SVN) }\end{array}$ \\
\hline \multicolumn{7}{|l|}{$\begin{array}{l}\text { UZUN } \\
\text { DÖNEM }\end{array}$} \\
\hline KOF & $-0.819 * * *$ & $0.008 * * *$ & $0.021 * *$ & $0.005 * * *$ & $0.138 * *$ & $-0.022 * *$ \\
\hline GSYH & $0.130 * * *$ & $0.232 * *$ & $0.083 * * *$ & $0.049 * * *$ & $0.045^{* * *}$ & $0.093 * * *$ \\
\hline TAX & $0.679 * * *$ & $1.082 * *$ & $-0.715 * * *$ & 0.060 & 0.015 & $-0.205^{* *}$ \\
\hline ENF & $-0.089 * * *$ & $-0.340 * *$ & $0.213 * * *$ & $0.036 * *$ & -0.008 & $0.118 * *$ \\
\hline \multicolumn{7}{|l|}{$\begin{array}{l}\text { KISA } \\
\text { DÖNEM }\end{array}$} \\
\hline KOF & 1.275 & 0.117 & -0.004 & $-5.305 * *$ & $-1.016^{* *}$ & -0.008 \\
\hline GSYH & $-0.717 * *$ & $-15.769 * * *$ & -0.556 & $-2.183^{* *}$ & -0.275 & -0.209 \\
\hline TAX & -0.102 & -0.897 & 0.0413 & -0.207 & 0.112 & -0.018 \\
\hline ENF & 0.006 & -0.086 & -0.001 & $-0.058 * *$ & 0.001 & -0.008 \\
\hline ECT(-1) & $-0.123 * *$ & $-0.192 * *$ & $-0.144 * *$ & $-0.122 * *$ & $-0.242 * *$ & $-0.102 * *$ \\
\hline $\begin{array}{l}\text { Hausman } \\
\text { Testi } \\
\text { Chi }^{\Lambda_{2}} \\
\text { (Olasılık) }\end{array}$ & $\begin{array}{c}0.73 \\
(0.865)\end{array}$ & $\begin{array}{c}3.27 \\
(0.351)\end{array}$ & $\begin{array}{c}0.52 \\
(0.914)\end{array}$ & $\begin{array}{c}4.10 \\
(0.244)\end{array}$ & $\begin{array}{c}1.28 \\
(0.734)\end{array}$ & $\begin{array}{c}1.12 \\
(0.771)\end{array}$ \\
\hline $\begin{array}{l}\text { Gözlem } \\
\text { Sayısı }\end{array}$ & 425 & 425 & 425 & 425 & 425 & 425 \\
\hline Ülke Sayısı & 28 & 28 & 28 & 28 & 28 & 28 \\
\hline
\end{tabular}

Not: $* * *, * * *, \% 10, \% 5$ ve $\% 1$ düzeyinde anlamlılı̆̆ 1 ifade etmektedir.

Elde edilen Hausman testi sonuçlarının olasılık değerlerinin \% 5 'ten büyük olması dolayısıyla Panel ARDL/PMG sonuçlarının yorumlanması gerektiği ortaya çıkmaktadır. Bu çerçevede, uzun dönemde, küreselleşmenin kamu harcamaları bileşenleri üzerindeki etkisi incelendiğinde, kamu harcamalarının alt bileşenlerinden genel kamu hizmetleri ve savunma harcamalarını negatif, diğer kamu harcamalarının alt bileşenlerini ise pozitif yönde etkilediği ortaya çıkmaktadır. Ayrıca, tüm kamu harcamaları bileşenlerinin GSYH değişkeninden pozitif yönde etkilendiği sonucuna ulaşılmıştır. Diğer taraftan vergi gelirlerindeki artış, genel kamu hizmetleri ve sosyal koruma harcamalarını pozitif, kamu düzeni ve güvenlik harcamaları ile savunma harcamalarını negatif yönde etkilemektedir. Son olarak, kamu harcamalarının enflasyondan etkilenme durumları incelendiğinde, enflasyondaki artıştan genel kamu hizmetleri ve sosyal koruma negatif, kamu düzeni ve güvenlik, eğitim ve savunma harcamalarının ise, pozitif yönde etkilendiği sonucuna ulaşılmıştır. Kısa dönemde ise, küreselleşme değişkeni ile eğitim ve sağlık harcamaları arasında anlamlı negatif bir ilişkinin söz konusu olduğu görülmektedir. Bunun yanında ekonomik büyüme, genel kamu hizmetleri, sosyal koruma ve eğitim harcamalarını negatif etkilerken, enflasyon da eğitim harcamalarını negatif etkilemektedir. Kurulan tüm modeller için hata düzeltme katsayısının istatistiki olarak anlamlı olması da hata düzeltme mekanizmasının işlediğini göstermektedir. 


\section{SONUÇ}

Birçok disiplinin çok yakından etkilendiği küreselleşmenin üzerinde en çok tartış1lan alanlarından birisi ulus-devletlerin egemenlik güçleri üzerinde yarattığı etki ile ilgilidir. Ulusdevletlerin egemenlik güçlerinin uluslararası/üstü kurumlara devrettiği fikrine karşılık küresel bir sistem içerisinde ulus-devletlerin hâlâ çok güçlü aktörler olduğunu ileri süren görüşler de mevcuttur. Küreselleşmenin ulusal ekonomiler üzerinde yarattığı etkinin sorgulandığ 1 çerçeve, kamu harcamaları ile olan ilişkisi ile ilgilidir. Neo-klasik çerçevede gelişen "verimlilik hipotezine" göre, devlet müdahalesi kaynak tahsisinde bozulmalara yol açtığ için devletin kamu harcamalarının bileşenlerinden, özellikle refah devletiyle özdeşleşen harcamaları sıfır toplamlı oyun haline gelmektedir. Verimlilik hipotezine karşı olarak, küreselleşme ile birlikte dışa açılan ülkelerin karşılaştığı dışsal riskler ve şoklara karşı kamu harcamalarının artacağını savunan kompansasyon hipotezi, neo-klasik görüşten farklılaşmaktadır. Dolayısıyla gelinen noktada ampirik literatürde, her iki yaklaşımı teyit eden ve doğrulamayan çok geniş araştırma sahası oluşmuştur. Bununla birlikte küreselleşmenin esas itibariyle refah devleti harcamalarına odaklanılması yanında, Dreher vd. (2008)'e göre küreselleşmenin refah harcamaları üzerindeki etkisini net olarak ölçebilmek için diğer kamusal harcama türlerinin de dikkate alınması gerekmektedir. Bu amaçla çalışmada Dreher vd. (2008)'nin analizinden hareketle 2001-2017 dönemi verileriyle, 28 AB ülkesi için küreselleşmenin kamu harcamalarının alt bileşenleri olan genel kamu hizmetleri, savunma harcamaları, kamu düzeni ve güvenlik, eğitim, sağlık ve sosyal koruma harcamaları üzerindeki etkisi incelenmiştir. Elde edilen sonuçlar küreselleşmenin, kamu düzeni ve güvenlik, eğitim, sağlık ve sosyal koruma harcamalarını pozitif; fakat genel kamu hizmetleri ve savunma harcamalarını ise negatif yönde etkilediğini göstermektedir. Diğer kontrol değişkenlerinin etkisine bakıldığında ise, GSYH tüm kamusal harcama türlerini pozitif yönde etkilerken, TAX değişkeni genel kamu hizmetleri ve sosyal koruma harcamalarını pozitif, kamu düzeni ve güvenlik harcamaları ile savunma harcamalarını negatif yönde etkilemektedir. ENF değişkeninden ise, genel kamu hizmetleri ve sosyal koruma harcamaları negatif, kamu düzeni ve güvenlik, eğitim ve savunma harcamalarının pozitif yönde etkilendiği sonucuna ulaşılmıştır. Analiz sonuçları, Dreher vd. (2008)'nin çalışmasıyla farklılık arz ederken Rodrik (1996)'in çalışmasıyla tutarlıdır.

Son dönemlerde Çin'den yayılarak tüm dünyayı etkisi altına alan yeni tip korona virüs (Covid-19) salgınıyla küreselleşme-ulus devlet ilişkisi yeniden tartışılmaya başlanmıştır. Sağlık alanında özel düzenlemelere sahip gelişmiş ülkelerin çoğunda sağlık sisteminin yetersiz kalması, kimi ülkelerde çökmesi ve özel sağlık hizmetlerinden yararlanma imkânı olmayan bireylerin ciddi sıkıntılar yaşaması, tüm dünyada kamu sektörünün bu alandaki gerekliliğini öne çıkarmıştır. Sağlık harcamaları yanında işlerini kaybedenlere ve firmalara yönelik sosyal transfer harcamaları devletin en çok başvurduğu harcama türü olmuştur. Bunun yanında devlet öncülüğünde piyasalara işlerlik kazandırılması amacıyla çeşitli teşvik ve kredi kolaylığı imkânı sağlanarak salgının etkileri azaltılmaya çalışılmıştır. Gelinen noktada küreselleşmenin ülkelere sunduğu firsatlar yanında teorik ve ampirik kısımda bahsedildiği gibi ulusal ekonomiler üzerinde birtakım risklere yol açtığı gözden kaçırılmamalıdır. $\mathrm{Bu}$ hususlar pratik alanda uygulanan politikalarla bir arada düşünüldüğünde, devletin küresel çağda ekonomik rollerinin minimize edilmesi gerektiği sadece söylem düzeyinde kalmaktadır. Çünkü dünyanın en liberal ülkeleri dahi pratikte devlet 
müdahalesine çok sık başvurmaktadır. Burada önemli olan husus, devletin ekonomide rollerinin azaltılması değil tam tersine verimli hâle getirilerek güçlendirilmesidir. Dolayısıyla küresel salgınla mücadelede, devletin ekonomide ne kadar önemli bir aktör olduğu bir kez daha ortaya çıkmıştır.

\section{KAYNAKÇA}

BERGH, A. \& KARLSSON, M. (2010). "Government Size and Growth: Accounting for Economic Freedom and Globalization”. Public Choice, 142: 195-213.

BRADY, D., BECKFIELD, J. \& SEELEIB-KAISER, M. (2005). "Economic Globalization and The Welfare State in Affluent Democracies, 1975-2001". American Sociological Review, 70(6): 921-948.

BRETSCHGER, L. \& HETTICH, F. (2002). "Globalisation, Capital Mobility and Tax Competition: Theory and Evidence for OECD Countries”. European Journal of Political Economy, 18: 695-716.

BUSEMEYER, M. R. (2009). "From Myth to Reality: Globalisation and Public Spending in OECD Countries Revisited”. European Journal of Political Research, 48: 455-482.

CAMERON, D. R. (1978). "The Expansion of the Public Economy: A Comparative Analysis". The American Political Science Review, 72(4): 1243-1261.

CARMIGNANI, F., COLOMBO, E. \& TIRELLI, P. (2007). "Public Expenditure and Growth Volatility: Do "Globalization" and Institutions Matter?". University of MilanoBicocca, Department of Economics Working Papers No. 116, 1-29.

DREHER, A. (2006). "The Influence of Globalization on Taxes and Social Policy: An Empirical Analysis for OECD Countries”. European Journal of Political Economy, 22: 179-201.

DREHER, A., STURM, J. E. \& URSPRUNG, H. W. (2008). “The Impact of Globalization on the Composition of Government Expenditures: Evidence From Panel Data". Public Choice, 134(3-4): 263-292.

GARRETT, G. (2001). "Globalization and Government Spending Around The World". Studies in Comparative International Development, 35(4): 3-29.

GARRETT, G. \& MITCHELL, D. (2001). "Globalization, Government Spending and Taxation in the OECD”. European Journal of Political Research, 39: 145-177.

GYGLI, S., HAELG, F., POTRAFKE, N., \& STURM, J. E. (2019). "The KOF Globalisation Index-Revisited". Review of International Organizations, 14(3): 543-574.

HA, E. (2008). "Globalization, Veto Players, And Welfare Spending”. Comparative Political Studies, 41(6): 783-813.

https://data.worldbank.org/indicator, 21.11.2019.

https://ec.europa.eu/eurostat/data/database, 18.11.2019.

KATZENSTEIN, P. J. (1985). Small States in World Markets: Industrial Policy in Europe. Cornell University Press, Ithaca \& London.

KIM, S. Y. (2007). "Openness, External Risk, and Volatility: Implications for The Compensation Hypothesis”. International Organization, 61(1): 181-216.

KIM, T. K. \& ZURLO, K. (2009). "How Does Economic Globalisation Affect The Welfare State? Focusing on The Mediating Effect of Welfare Regimes". International Journal of Social Welfare, 18(2): 130-141.

IM, K., PESARAN, M.H. \& SHIN, Y. (2003). "Testing for Unit Roots in Heterogeneous Panels". Journal of Econometrics, 115(1): 53-74. 
LIBERATI, P. (2007). “Trade Openness, Capital Openness and Government Size”. Journal of Public Policy, 27(2): 215-247.

QUINN, D. (1997). "The Correlates of Change in International Financial Regulation”. American Political Science Review, 91(3): 531-551.

NAZLIOGLLU, Ş. (2011). "Tarımsal Fiyatlarda Hedefi Aşma Hipotezi: Gelişmiş ve Gelişmekte Olan Ülkeler İçin Panel ARDL Analizi”. Finans Politik \& Ekonomik Yorumlar, 48(556): 67-80.

PESARAN, M. H. (2007). "A Simple Panel Unit Root Test in The Presence of Cross-Section Dependence". Journal of Applied Econometrics, 22(2): 265-312.

RODRIK, D. (1996). “Why Do More Open Economies Have Bigger Governments?”. NBER Working Paper Series, Working Paper 5537: 1-27.

RODRIK, D. (2011). Akıllı Küreselleşme, Burcu Aksu (Çev). Efil Yayınevi, Ankara.

SANZ, I. \& VELÁZQUEZ, F. J. (2003). "Does Globalization Increase Government Size? An Analysis of The Effects of Foreign Direct Investment on Total Government Expenditures and Its Components". European Economy Group-UCM and FUNCAS, $1-19$.

SHAHBAZ, M., REHMAN, H. U. \& AMIR, N. (2010). "The Impact of Trade and FinancialOpenness on Government Size: A Case Study of Pakistan”. Journal of Quality and Technology Management, 6(1): 105-118.

SWANK, D. (2002). Global Capital, Political Institutions and Policy Change in Developed Welfare States. Cambridge University Press, Cambridge.

UNCTAD (2019), https://unctadstat.unctad.org/wds/TableViewer/tableView.aspx, 18.11.2019.

WU, T. P., FAN, D. \& CHANG, T. (2016). "The Relationship Between Globalization and Military Expenditures in G7 Countries: Evidence From A Panel Data Analysis". Economic Computation \& Economic Cybernetics Studies \& Research, 50(3): 285-302. 